\title{
Biochemical and molecular characterization of induced resistance against Penicillium digitatum in citrus fruit
}

A. R. Ballester ${ }^{\mathrm{ab}}$, A. Izquierdo ${ }^{\mathrm{a}}$, M. T. Lafuente ${ }^{\mathrm{a}}$ and L. González-Candelas ${ }^{\mathrm{a} *}$

${ }^{a}$ Instituto de Agroquímica y Tecnología de Alimentos (IATA). Consejo Superior de Investigaciones Científicas (CSIC). Apartado de Correos 73, Burjassot 46100, Valencia. Spain. E-mail: lgonzalez@iata.csic.es; Telephone: 34-963900022; Fax: 34-963636301.

${ }^{b}$ Present address: Plant Research International, PO Box 16, 6700 AA Wageningen, The Netherlands

*To whom correspondence should be addressed 


\section{ABSTRACT}

2 To get an insight into the mechanisms underlying resistance of citrus fruit against

3 Penicillium digitatum, we have analyzed at the enzyme activity and gene expression

4 levels the possible involvement of phenylalanine ammonia-lyase (PAL), peroxidase,

$5 \quad \beta$-1,3-glucanase and chitinase in the flavedo (outer colored part of the fruit peel) and

6 albedo (the inner white part) in elicited fruit. As a tool to induce resistance, we

7 inoculated oranges with $P$. digitatum and 1 day later fruits were exposed to a hot air

8 treatment at $37^{\circ} \mathrm{C}$ for 3 days. Our results showed that all enzyme activities increased

9 in parallel with increased resistance, especially in the albedo, although the highest

10 activities were generally found in the flavedo. Expression of the PAL encoding gene

11 and that of the genes coding for the basic, rather than for the acidic, isoforms of the

12 PR proteins were also induced in both tissues, but most remarkably in the albedo.

15 KEYWORDS: chitinase; citrus fruit; gene expression; glucanase; induced resistance;

16 infection; Penicillium digitatum; peroxidase; phenylalanine ammonia-lyase; PR 17 proteins; scoparone 


\section{INTRODUCTION}

Green and blue mold rots, caused by Penicillium digitatum (Pers.:Fr.) Sacc. and Penicillium italicum Wehmer, respectively, are the most important postharvest diseases of citrus fruit grown under Mediterranean climate conditions. Both pathogens are necrotrophs that require wounds to enter the fruit through the flavedo. Although synthetic fungicides have a major role in reducing postharvest losses due to fungal decay, problems associated with their widespread use as well as the increasing awareness of their associated health and environmental risks have promoted the search for new and safer alternatives. Besides these concerns, the proliferation of resistant strains is a serious risk to the effectiveness of fungicides. Additionally, the number of wholesalers and final retailers that require produce with lower chemical residue levels than official requirements is growing steadily (WTO, 2009).

Increasing the fruit's natural defense capabilities through induction of resistance is one of the alternative strategies being investigated as a means to reduce the use of chemical fungicides during postharvest handling and storage of fruits and vegetables. In fully mature citrus fruit, increased resistance against $P$. digitatum infection can be achieved by application of physical (Kim et al., 1991; Ben Yehoshua et al., 1992; Rodov et al., 1992; Droby et al., 1993; Arcas et al., 2000), chemical (Porat et al., 2001; 2002; Venditti et al., 2005), or antagonistic microorganisms treatments (Arras, 1996; Fajardo et al., 1998; Droby et al., 2002). The efficacy of these treatments in eliciting induced resistance is variable, and in many instances depends on the maturity stage of the fruit. Although understanding the mechanisms underlying induced resistance would help to improve the development of this alternative strategy, our knowledge of the biochemical and molecular bases of induced resistance is very poor. In only a few studies have the induction of pathogenesis-related (PR) proteins, 
1 synthesis of phytoalexins and $\beta-1,3$-glucanase and chitinase gene expression been analyzed in the context of induced resistance in citrus fruit, as discussed below.

UV irradiation, hot water and biocontrol yeast elicitation of fruit resistance is accompanied by induction of the PR proteins chitinase and $\beta$-1,3-glucanase (Porat et al., 1999; 2001). However, Fajardo et al. (1998) did not find induction of PR proteins in the flavedo of oranges treated with different biological derived elicitors and then inoculated with $P$. digitatum. Lignification and accumulation of phenolic compounds have also been associated with the resistance of citrus fruit to P. digitatum infection (1991; Angioni et al., 1998; 1999; Ortuño et al., 2006). The levels of the antifungal scoparone in the flavedo of citrus fruit rose to fungicidal levels in pathogenchallenged fruit that were subsequently subjected to a heat treatment, but pathogen infection did not promote such an increase (Kim et al., 1991). Induction of this citrus phytoalexin has also been observed in UV-irradiated fruit (Rodov et al., 1992) or after elicitation of resistance by antagonistic yeasts (Arras, 1996; Droby et al., 2002). Therefore, scoparone has been considered a good marker of induced resistance in citrus fruit.

PAL and peroxidase activities are induced in grapefruit after elicitation of resistance by UV irradiation (Droby et al., 1993) or by the biocontrol yeast Candida oleophila (Droby et al., 2002). PAL is the first enzyme in the phenylpropanoid pathway, from which scoparone and scopoletin are synthesized. On the other hand, peroxidases play a key role at a later stage in the pathway during the synthesis of lignin, which acts as a cell wall reinforcement enhancing resistance against multiple pathogens, and may alter the antioxidant ability of citrus fruit to cope with Penicillium infection (Ballester et al., 2006). In this regard, it is noteworthy that both enzymes have been suggested to play a role in the defense response of citrus fruit against $P$. digitatum (Ballester et al., 
1 2006), although their transcriptional regulation during development of induced

2 resistance in citrus fruit remains unknown. In addition, previous studies indicate that

3 the albedo is more susceptible to P. digitatum infection than the external flavedo

4 (Kavanagh and Wood, 1967; Ballester et al., 2006), which suggests that defense

5 responses triggered in the inner tissue should be more critical to resistance.

6 Nevertheless, the responses of the albedo to elicitors that increase resistance to

7 pathogen attack have barely been studied (1999; Venditti et al., 2005).

8 The objective of the present work was to analyze gene regulation and enzyme

9 activities of PAL, peroxidase, $\beta$-1,3-glucanase and chitinase in flavedo and albedo

10 tissues of oranges that had been previously inoculated with P. digitatum and 1 day

11 later were cured for 3 days at $37{ }^{\circ} \mathrm{C}$ (Kim et al., 1991). This treatment was selected 12 because of its high reproducibility and efficacy in eliciting the induction of the 13 phytoalexin scoparone, which, as mentioned before, is considered a good marker of 14 induced resistance in citrus fruit.

MATERIALS AND METHODS

\section{Plant and fungal material}

Mature oranges (Citrus sinensis L. Obseck) from the cultivar 'Navelate' were harvested from adult trees grown at Lliria, Valencia, Spain and processed the same

21 day. Fruit were surface-sterilized with a 5\% commercial bleach solution for 5 min, extensively washed with tap water and allowed to dry at room temperature until next day.

Penicillium digitatum (Pers.: Fr.) Sacc. isolate PHI-26 used in this study was obtained from a rotten orange and cultured on potato dextrose agar (Difco, Detroit, USA) plates at $24^{\circ} \mathrm{C}$ (López-García et al., 2000). Conidia from a 7-day-old culture were collected 
1 by scraping them with a sterile spatula and transferred to sterile water. Conidia

2 suspension was then filtered and the concentration determined with a

3 haemocytometer.

$5 \quad$ Induction of resistance treatment

6 Fig. 1 represents a schematic diagram indicating tissue sampling and pathogen 7 inoculation for each treatment. Fruit were wounded by making punctures 8 (approximately $3 \mathrm{~mm}$ in depth) with a sterilized nail and inoculated with $10 \mu \mathrm{L}$ of a 9 P. digitatum conidial suspension adjusted to $10^{5}$ conidia per $\mathrm{mL}$. Inoculated fruit were 10 arranged in plastic boxes and maintained at $90-95 \%$ relative humidity $(\mathrm{RH})$ and $20^{\circ} \mathrm{C}$ 11 for 1 day to allow pathogen development. Then, fruit were heat-treated at $37^{\circ} \mathrm{C}$ for 123 days under water-saturated conditions (curing) in order to stop the progress of the pathogen. After the heat treatment, fruit were maintained at $20^{\circ} \mathrm{C}$ and $90-95 \% \mathrm{RH}$. At 3 days post-treatment (dpt), 7 days from the beginning of the experiment, peel tissue discs of $13 \mathrm{~mm}$ in diameter around the inoculation site were sampled by using a cork borer (Sample I). Control inoculations without pathogen were carried out by injecting $1710 \mu \mathrm{L}$ of sterile water and holding the fruit under the same conditions (Sample $\mathrm{W}$ ). An additional control consisted of intact non-wounded fruit held at $20^{\circ} \mathrm{C}$ for 1 day and 19 then at $37^{\circ} \mathrm{C}$ for 3 days (Sample $\mathrm{C}$ ). With this experimental design we can asses 20 independently the effect of the pathogen and the wound response. Moreover, tissue 21 from non-treated fruit was obtained the first day of the experiment (Sample NT). 22 Flavedo and albedo tissues were separated with a scalpel. Tissue discs obtained from 2315 fruits ( 8 discs per fruit) were immediately frozen in liquid nitrogen, mixed and 24 grounded to a fine powder with a coffee mill and stored at $-80^{\circ} \mathrm{C}$ until further analysis. 
1 To asses the effectiveness of the induction of resistance treatment, disease

2 susceptibility was analyzed both at the beginning of the experiment in non-treated

3 fruit and at $3 \mathrm{dpt}$ for the remaining treatments. Each fruit was punched at a distance

4 of $0.5 \mathrm{~cm}$ from the previous wound or in the equatorial axis in fruit that had not been

5 previously inoculated. Thereafter, $10 \mu \mathrm{L}$ of a suspension of $P$. digitatum containing

$6 \quad 10^{4}$ conidia per $\mathrm{mL}$ were inoculated into each wound. This lower inoculum level was

$7 \quad$ selected to avoid a very rapid disease progression that could mask differences among

8 treatments. Inoculated fruit were arranged separately on plastic boxes and maintained

9 at $90-95 \% \mathrm{RH}$ and $20^{\circ} \mathrm{C}$ for 6 days. The incidence (percentage of lesions) and the

10 severity (maceration area, in $\mathrm{cm}^{2}$ ) of the infection were assessed at 6 days post-

11 inoculation (dpi). The experimental design consisted of 3 replicates of 5 fruits, with 4

12 wounds per fruit, for each treatment. To test the effect of the treatments, a one-way

13 analysis of variance (ANOVA) was performed. Means were separated using the

14 Tukey's Honestly Significant Difference test at $p<0.05$. The analysis was preformed 15 with Statgraphics Plus 5.1 Software (Manugistics, Inc.).

17 Extraction and quantification of scoparone

18 Phenolic compounds were extracted from $100 \mathrm{mg}$ of tissue in $2 \mathrm{~mL}$ tubes containing

19 five $1.2 \mathrm{~mm}$ steel beads and $500 \mu \mathrm{L}$ of $80 \%$ methanol with the aid of a Mini 20 Beadbeater 8 Cell Disruptor (Biospec Products, Inc.). Samples were extracted twice 21 at $4^{\circ} \mathrm{C}$ for $1 \mathrm{~min}$, centrifuged at $11600 \times g$ for $10 \mathrm{~min}$ at $4^{\circ} \mathrm{C}$ to eliminate cell debris 22 and the supernatants were filtered through $0.45 \mu \mathrm{m}$ polytetrafluoroethylene (PTFE) 23 Millipore filters. Samples were immediately analyzed by HPLC using a Waters liquid 24 chromatography system equipped with a Waters 600 quaternary pump, a Waters 474 25 fluorescence detector, a Waters 2996 photodiode array detector and the Empower 
1 Software (Waters). A Luna C18 (Phenomenex, Inc.) column $(250$ x $4.6 \mathrm{~mm}, 5 \mu \mathrm{m})$ coupled to a guard column $\mu$ Bondapak C18 (Waters) $(10 \mu \mathrm{m})$ was used and phenolic compounds were separated at $35^{\circ} \mathrm{C}$ using a binary gradient of water (A), brought to pH 2.5 with phosphoric acid, and acetonitrile (B). The initial solvent composition consisted of $99 \% \mathrm{~A}$ and $1 \% \mathrm{~B}$. The solvent composition changed in a linear gradient to $70 \% \mathrm{~A}$ and $30 \% \mathrm{~B}$ during $60 \mathrm{~min}$. During the next $45 \mathrm{~min}$ (105 min running time), the solvent composition was changed to $1 \% \mathrm{~A}$ and $99 \% \mathrm{~B}$, and then kept for $10 \mathrm{~min}$. Initial conditions were reestablished in $1 \mathrm{~min}$ and the column was reequilibrated for $24 \mathrm{~min}$ before the next injection. The flow rate was $0.8 \mathrm{~mL}$ per min and the injection volume was $20 \mu \mathrm{L}$. Phenolics were detected by fluorescence at excitation and emission wavelengths of 313 and of $405 \mathrm{~nm}$, respectively, and by setting the photodiode array detector to scan from 200 to $400 \mathrm{~nm}$. Scoparone was identified by comparison of the spectrum and retention time with an authentic standard and quantified by peak area comparison using a standard curve. Each result is the mean of 3 replicate samples. Tukey's test was performed to identify significant differences between samples at $p<0.05$.

\section{RNA extraction and Northern analysis}

Total RNA was isolated from the flavedo and the albedo tissues according to Ballester et al. (2006). RNA (10 $\mu \mathrm{g}$ per lane) was electrophoresed through a formaldehyde gel and blotted onto a Hybond- $\mathrm{N}^{+}$membrane (GE Healthcare). cDNA probes were labeled with $\alpha\left({ }^{32} \mathrm{P}\right)$-dATP by using the Strip-EZ ${ }^{\mathrm{TM}}$ PCR kit (Ambion, Inc.). Blots were hybridized overnight at $42^{\circ} \mathrm{C}$ in Ultrahyb ${ }^{\mathrm{TM}}$ Ultrasenstive Hybridization buffer (Ambion, Inc.) and then washed once at $55^{\circ} \mathrm{C}$ for $15 \mathrm{~min}$ in $2 \mathrm{X} \mathrm{SSC}$ and $0.1 \% \mathrm{SDS}$ $(\mathrm{w} / \mathrm{v})$ and twice in $0.1 \mathrm{X} \mathrm{SSC}$ and $0.1 \% \operatorname{SDS}(\mathrm{w} / \mathrm{v})$ at $55^{\circ} \mathrm{C}$ for $30 \mathrm{~min}$. Blots were 
1 quantified by exposure to a BAS MP 2040 Imaging Plate (Fuji Photo Film Co.,

2 LTD.), scanned with a FLA-3000 laser scanner (Fuji Photo Film Co., LTD.) and

3 quantified with the software ImageGauge V4.0 (Science Lab 98, Fuji Photo Film Co.,

4 LTD.). After stripping off the probe following the instructions in the Strip-EZ ${ }^{\mathrm{TM}}$ PCR

5 kit, membranes were rehybridized with different probes. Hybridization signals were

6 normalized according to the $C$. sinensis 26S rRNA signal intensity in each sample.

7 Probes used for Northern hybridization were obtained from different cDNA libraries

8 generated previously in our group. A full-length cDNA clone, FPal1 (GeneBank Acc.

9 No. AJ238753), was isolated from the flavedo of 'Fortune' mandarins stored at $1^{\circ} \mathrm{C}$

10 (Sánchez-Ballesta et al., 2000). A full-length cDNA encoding an acidic class III $\beta$ -

11 1,3-glucanase (CrglcQ, Acc. No. AY971953) was isolated from the same library

12 (Sánchez-Ballesta et al., 2006). A cDNA corresponding to the basic $\beta$-1,3-glucanase

13 gns1 gene isolated by McCollum et al. (1999) (Acc. No. AJ000081) was obtained

14 from the RindPdig24 cDNA library, which is derived from 'Clemenules' mandarins

15 infected with P. digitatum (Acc. No. CX298651) (Forment et al., 2005). These two $\beta$ -

16 1,3-glucanase encoding genes shared an $82 \%$ identity at the amino acid level. Two

17 different cDNAs encoding a basic extracellular peroxidase (Acc. No. CX297694,

18 designated pox1) that shares a 70\% identity with the Citrus maxima POD1 gene and

19 an acidic one (Acc. No. CX299378, designated pox2) were isolated from the cDNA

20 libraries RindPdig24 and FlavCurFr1, respectively. The latter library was obtained

21 from heat-treated 'Fortune' mandarins (Forment et al., 2005). Comparison of the

22 nucleotide sequences revealed that these two cDNAs shared low homology (less than

23 47\%). Two different cDNAs encoding chitinases were isolated from the same two

24 libraries. The first one (Acc. No. CX299099) was obtained from RindPdig24 and

25 showed $99 \%$ identity with the basic chitinase encoding gene chi1 isolated by Porat et 
1 al. (2001) (Acc. No. AF090336). The second chitinase gene, designated chi2, was

2 obtained from FlavCurFr1 (Acc. No. CX298387) and shares 95\% identity with a class

3 II acidic chitinase gene isolated by Osswald et al. (1994). The C. sinensis 26S rDNA

4 (Acc. No. AJ969115) and the P. digitatum 28S rDNA (Acc. No. AJ969116) probes

5 were obtained previously by Ballester et al. (2006).

6 DNA fragments used for probe labeling were obtained by PCR using the

7 corresponding plasmids as templates and the primers FOR17 (5'-GTT TTC CCA

8 GTC ACG AC-3') and REV17 (5'-CAG GAA ACA GCT ATG AC-3'). PCR

9 conditions were $94^{\circ} \mathrm{C}$ for $3 \mathrm{~min}$, then $94^{\circ} \mathrm{C}$ for $30 \mathrm{~s}, 56^{\circ} \mathrm{C}$ for $45 \mathrm{~s}$ and $72^{\circ} \mathrm{C}$ for $2 \mathrm{~min}$

10 for 35 cycles, followed by a final elongation step of 10 min at $72^{\circ} \mathrm{C}$. DNA fragments

11 were purified with the High Pure PCR Product Purification kit (Roche Applied

12 Sciences) and quantified by measuring the fluorescence with the Ribogreen ${ }^{\circledR}$ dye

13 (Molecular Probe, Inc.).

\section{Enzyme assays}

16 All enzyme assays were determined from 3 replicate samples using a Hewlett Packard 17 8452A spectrophotometer connected to a thermostatized water bath. Crude extracts were obtained with a Mini Beadbeater 8 Cell Disruptor (Biospec Productor, Inc.) in 2

$19 \mathrm{~mL}$ tubes containing five $1.2 \mathrm{~mm}$ steel beads. Samples were extracted twice at $4^{\circ} \mathrm{C}$ for $201 \mathrm{~min}$ with a specific buffer and centrifuged at $11600 \mathrm{x} \mathrm{g}$ for $10 \mathrm{~min}$ at $4^{\circ} \mathrm{C}$ to 21 eliminate cell debris. The supernatant was used to analyze enzyme activities.

22 PAL, $\beta$-1,3-glucanase and chitinase activities were extracted from acetone powder. 23 Five grams of frozen tissue were ground in $50 \mathrm{~mL}$ of acetone, previously chilled at $2420^{\circ} \mathrm{C}$. The homogenate was filtered through a Buchner funnel, the residue washed 
1 once with cold acetone and the resulting powder dried for $2 \mathrm{~h}$ at room temperature.

2 The acetone powder was stored at $-80^{\circ} \mathrm{C}$ until use for enzymatic assays.

3 PAL (EC 4.3.1.24) activity was extracted as previously described by Ballester et al.

4 (2006) from acetone powder. The reaction mixtures $(2 \mathrm{~mL})$ contained $660 \mu \mathrm{L}$ of the

5 partially purified enzyme and $200 \mu \mathrm{L}$ of $100 \mathrm{mM}$ L-phenylalanine. PAL activity was

6 determined by measuring the absorbance of cinnamic acid at $290 \mathrm{~nm}$ over a period of

$7 \quad 2 \mathrm{~h}$ at $40^{\circ} \mathrm{C}$. Enzyme activity was expressed as nmoles of cinnamic acid per $\mathrm{g}$ of

8 acetone powder tissue per $\mathrm{h}$.

9 Enzyme extraction and enzymatic assays for peroxidase (EC 1.11.1.7) activity were

10 conducted as described by Ballester et al. (2006). Enzyme activity was expressed as

11 the increase in absorbance at $470 \mathrm{~nm}$ per min per $\mathrm{g}$ of fresh weight tissue.

$\beta$-1,3-glucanase (EC 3.2.1.6) activity was measured using the colorimetric assay based on the hydrolysis of laminarin (Abeles and Forrence, 1970). The enzyme was extracted from $25 \mathrm{mg}$ of flavedo or albedo acetone powder with $1.5 \mathrm{~mL}$ of $100 \mathrm{mM}$ potassium phosphate buffer, $\mathrm{pH} 7.0$, including 3\% polyvinylpyrrolidone (PVPP). The

16 reaction mixture contained $10 \mu \mathrm{L}$ of the supernatant, $215 \mu \mathrm{L}$ of $100 \mathrm{mM}$ sodium 17 acetate, $\mathrm{pH} 5.0$, and $75 \mu \mathrm{L}$ of $2 \%$ laminarin. The mixture was incubated at $50^{\circ} \mathrm{C}$ for 1 or $2 \mathrm{~h}$ for the flavedo and albedo, respectively. The reaction was stopped by adding $600 \mu \mathrm{L}$ of $1 \%$ dinitrosalicylic reagent and heating the tubes for $5 \mathrm{~min}$ at $100^{\circ} \mathrm{C}$. Absorbance of the samples was measured at $540 \mathrm{~nm}$. A standard curve was 21 constructed using glucose and the activity expressed as $\mu$ moles of glucose per $\mathrm{h}$ per $\mathrm{g}$ 22 of acetone powder.

23 Chitinase (EC 3.2.1.14) activity assay was based on the protocol described by Fajardo 24 et al. (1998) with minor modifications. Acetone powder (15 mg) was homogenized 25 with $1.5 \mathrm{~mL}$ of $20 \mathrm{mM}$ potassium phosphate buffer, $\mathrm{pH} 7.0$, containing 3\% PVPP and 
1 the enzyme was extracted by cell disruption and centrifugation. The assay mixture contained $20 \mu \mathrm{L}$ of the supernatant, $15 \mu \mathrm{L}$ of $2 \mathrm{M}$ sodium acetate buffer, $\mathrm{pH}$ 5.0, $150 \mu \mathrm{L}$ of carboxymethyl-chitin-remazol brilliant violet and $415 \mu \mathrm{L}$ of $\mathrm{H}_{2} \mathrm{O}$. Reaction mixtures were incubated at $37^{\circ} \mathrm{C}$ for $15 \mathrm{~min}$. The reaction was stopped by adding $150 \mu \mathrm{L}$ of $1 \mathrm{~N}$ hydrochloric acid and the mixture was immediately cooled on ice for $10 \mathrm{~min}$. Absorbance of samples was measured at $550 \mathrm{~nm}$. Enzyme activity was expressed as the increase in absorbance at $550 \mathrm{~nm}$ per min per $\mathrm{g}$ of acetone powder.

\section{Statistics}

Enzyme activity values were the mean of 3 replicate samples \pm SD. Data were further subjected to analysis of variance followed by Tukey's test with Statgraphics Plus 5.1 Software (Manugistics, Inc.). Differences at $p<0.05$ were considered significant.

\section{RESULTS}

\section{Induction of resistance in citrus fruit against $P$. digitatum and scoparone levels}

Although previous reports have shown that the combination of pathogen challenge followed by a curing treatment elicited a high level of the phytoalexin scoparone in the peel of citrus fruit, nothing is known about the effectiveness of this treatment increasing fruit's resistance to a subsequent pathogen attack. Our results showed that this treatment (treatment I) significantly reduced both disease incidence and severity (Table 1). Wounded-cured fruit also showed a statistically significant, but lower, reduction in disease intensity. In contrast, fruit only subjected to the heat treatment at $37^{\circ} \mathrm{C}$ for 3 days (C) showed the highest values of disease incidence and severity.

Scoparone concentration was determined in the flavedo and albedo tissues. As shown in Table 2, scoparone was not detected in non-treated fruit and its concentration was 
1 very low in the flavedo and albedo of cured oranges. However, substantial amounts of

2 scoparone were detected in the flavedo, and to a lower extent in the albedo, of

3 infected-cured fruit. The level of scoparone in wounded-cured fruit also increased, but

4 not as much as in response to the infection-curing treatment.

\section{$6 \quad$ FPal1 gene expression and PAL activity in elicited fruit}

7 The accumulation of FPal1 mRNA and PAL activity were studied in the flavedo and 8 albedo tissues of fruit subjected to the treatment that induced resistance (Fig. 2A).

9 Hybridization with the C. sinensis ribosomal probe allowed normalization of FPal1 10 gene expression values, whereas the lack of hybridization signal with the $P$. digitatum 11 ribosomal probe indicated that the pathogen did not progress through the tissue in fruit that had previously been inoculated with the pathogen (treatment I). In control nontreated fruit, FPal1 gene expression was only detected in the flavedo and the highest expression was found in infected-cured fruit. In the albedo, expression was only detected in this latter treatment. Thus, the observed induction with respect to non16 treated fruit is more relevant in this inner tissue.

17 The pattern of PAL activity was similar in flavedo and albedo, although the activity in non-treated fruit was almost 10-fold higher in the flavedo (Fig. 2B). The highest activity was observed in both tissues in infected-cured fruit. PAL activity was 16-fold higher in the flavedo of these fruits as compared with that of non-treated oranges, 21 whereas in the albedo the induction was 70-fold. PAL activity was also induced in response to the wounding-curing treatment, albeit to a lower extent, reaching a 6- and 15-fold induction as compared with non-treated fruit in the flavedo and albedo, respectively. On the other hand, curing did not cause any induction of PAL activity. 


\section{Peroxidase gene expression and activity in elicited fruit}

2 The involvement of two novel different peroxidase genes previously isolated from

3 'Clemenules' mandarins infected with P. digitatum (pox1) and from heat-treated

4 'Fortune' mandarins (pox2) in the induction of resistance against P. digitatum in

5 'Navelate' oranges has been investigated. Northern analyses using both genes as

6 probes revealed different patterns of expression (Fig. 3A). The accumulation of pox1

7 and pox 2 mRNAs in the flavedo of non-treated fruit was higher than in the albedo. In

8 both tissues, the highest level of pox1 gene expression was detected in infected-cured

9 fruit. Wounding and subsequent heat-treatment slightly induced the expression of

10 pox 1 mRNA in the flavedo, but not in the albedo. However, the heat-treatment alone

11 resulted in a lower accumulation of the transcript in the flavedo. On the other hand,

12 pox2 expression level decreased in both tissues in all treatments as compared with

13 non-treated fruit.

14 Changes in soluble and insoluble peroxidase activities in the flavedo and albedo

15 tissues are shown in Fig. 3B. The most noticeable difference observed between the

16 two activities in both tissues is the low overall level of soluble peroxidase activity in

17 the albedo, which in non-treated fruit was 8-fold lower than in the external tissue and

18 16-fold lower than its insoluble peroxidase activity counterpart. The trend of changes

19 in soluble and insoluble peroxidase activities was similar in the flavedo. Curing alone

20 did not significantly modify either activity. However, wounded-cured fruit showed an

21 increase in both peroxidase activities, which reached the highest values in infected-

22 cured fruit. In the albedo, the highest soluble peroxidase activity was also detected in

23 infected-cured fruit, although it was 6-fold lower than in the external tissue of fruit

24 subjected to the same treatment. On the other hand, insoluble peroxidase activity in

25 the albedo remained quite unaltered in all treatments. 


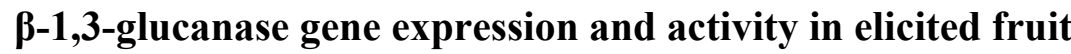

3 The expression patterns of gns1 and the larger CrglucQ transcript were similar (Fig.

4 4A). For both genes, the expression in the flavedo was higher than in the albedo, and

5 the maximum induction was detected in infected-cured oranges in both tissues.

6 However, the induction of gns1 expression was higher than that of the larger CrglucQ

7 transcript in both tissues. A lower induction of both genes was also observed in the

8 flavedo of wounded-cured fruit, but their expression did not increase in the albedo.

9 The overall pattern of $\beta$-1,3-glucanase activity was similar in flavedo and albedo (Fig.

10 4B), although the activity in the flavedo of non-treated fruit was almost 5 times higher

11 than in the underlying albedo. The highest activity was observed in cured fruit previously infected with $P$. digitatum. The induction level with respect to control nontreated fruit was slightly higher in the inner tissue, about 5-fold induction. A lower induction, 1.4-fold, was also found in both tissues in wounded-cured fruit, but heattreatment alone did not induce $\beta$-1,3-glucanase activity.

\section{Chitinase gene expression and activity in elicited fruit}

The expression of two different chitinase genes isolated from 'Clemenules' mandarins infected with P. digitatum (chi1) or from heat-stressed 'Fortune' mandarins (chi2) was analyzed (Fig. 5A). Both genes showed different patterns of expression. The highest chi1 transcript accumulation was observed in infected-cured oranges, being the expression in the albedo lower than in the flavedo. An important increase in chi1 gene expression was also detected in the flavedo of wounded-cured fruit, but not in the albedo. However, chi2 expression was only induced in the flavedo of wounded- 
1 cured fruit. It is interesting to note that the expression of the two chi gene was

2 negligible in the albedo of cured or wounded-cured fruit.

3 Chitinase was the only studied enzyme whose activity was higher in the albedo than

4 in the flavedo of non-treated fruit (Fig. 5B). An increase in this activity was observed

5 in the flavedo and albedo of infected-cured fruit, being higher in the flavedo. A slight

6 increase was also found in the flavedo of wounded-cured fruit, but there were no

7 significant differences in the albedo. On the other hand, curing itself did not induce

8 the activity or even led to a slight decrease.

\section{DISCUSSION}

Increasing fruit's natural resistance to pathogens is one of the alternatives being explored in the effort to reduce the dependency on chemical fungicides. Although many efforts have been invested in the practical implementation of induced resistance in mature citrus fruit against P. digitatum infection, we have only gathered partial information on the mechanisms responsible for this process, as no comprehensive study has been conducted. Induced resistance has been associated with the novo synthesis of phytoalexins and induction of the PR proteins $\beta$-1,3-glucanase and chitinase in the flavedo of elicited fruits. However, a detailed study of induced resistance in citrus fruit including analysis of enzyme activities, genes and metabolites has not been addressed yet. Moreover, the possible role of the most susceptible albedo tissue in the induction of resistance remains to be investigated.

Kim et al. (1991) showed that the inoculation of mature lemons with P. digitatum followed $24 \mathrm{~h}$ later by a heat treatment increased the concentration of the phenolic compound scoparone to fungicide levels in the flavedo. However, the effectiveness of this treatment in eliciting increased resistance to a subsequent pathogen infection was 
1 not investigated. The present study demonstrates that this treatment decreased the

2 susceptibility of orange fruit to a subsequent $P$. digitatum infection (Table 1). The

3 curative effect of high temperature in the form of either hot water dips or curing has

4 been previously reported in citrus and tomato fruits (Brown et al., 1978; Lurie et al.,

5 1997; Nafussi et al., 2001). In agreement with these findings, we have found that none

6 of the 'Navelate' oranges inoculated with P. digitatum and 1 day later cured at $37^{\circ} \mathrm{C}$

7 for 3 days under water-saturated conditions developed infection (data not shown).

8 However, in spite of the high curative effect of this treatment, curing per se was not a

9 preventive treatment, as cured fruit showed a higher disease incidence than non-

10 treated fruit (Table 1). These results reinforce the idea that the curing treatment might

11 be an eradicative tool for incipient infections, but also point out the higher

12 susceptibility of cured fruit to a subsequent pathogen infection that may occur during

13 handling of the fruit after the heat treatment. Likewise, the combination of wounding

14 and high temperature may induce disease resistance at a close distance from the

15 wounding site, but to a lower extent than the combination of pathogen challenge and

16 curing. The fact that pathogen infected-cured fruit developed higher resistance than

17 wounded-cured fruit suggests that elicitors produced either directly or indirectly by

18 the pathogen are able to trigger a defense response strong enough to increase

19 significantly the resistance of the fruit to a subsequent pathogen attack, although, as

20 mentioned above, the fungus was not able to colonize the host tissue.

21 The present study shows that the highest activity of almost all the enzymes analyzed, 22 was detected in the flavedo of infected-cured orange fruit, except for the chitinase 23 activity, which was higher in the inner tissue. The same fact was observed at the gene 24 expression level, as mRNA accumulation was higher in the flavedo of elicited 25 oranges, but induction was higher in the albedo. These results reinforce the idea that 
1 the albedo is less resistant to P. digitatum infection (Kavanagh and Wood, 1967; Afek

2 et al., 1999; Ballester et al., 2006). However, it is noteworthy that this inner tissue

3 showed the highest induction level of PAL, soluble peroxidase and $\beta$-1,3-glucanase

4 activities. Therefore, it seems plausible to hypothesize that the activation of a

5 combined group of defense responses in the albedo is necessary to deter P. digitatum

6 infection.

7 PAL is the first committed enzyme in the pathway leading to the biosynthesis of

8 phenolic compounds, such as scoparone, in higher plants. The involvement of PAL in

9 the defense of citrus fruit against Penicillium has been suggested by examining

10 changes in $P A L$ gene expression in response to infection (Marcos et al., 2005;

11 Ballester et al., 2006) or in PAL activity in fruit exposed to treatments such as UV

12 light (Droby et al., 1993) and chemical or biological elicitors (Fajardo et al., 1998)

13 that induce resistance against this pathogen. However, this is the first work reporting

14 the expression pattern of this important gene during elicitation of induced resistance

15 in citrus fruit. Our results showed that the highest levels of FPa1l gene expression and

16 PAL enzymatic activity occurred in infected-cured fruit (Fig. 2). This induction might

17 be directly related to the lower susceptibility of elicited oranges fruit against a

18 subsequent $P$. digitatum infection. Among all the enzyme activities analyzed, PAL is

19 the one that showed the largest induction in response to the treatments that increase

20 the fruit's resistance. This induction was highest in the albedo, reaching a 70-fold

21 induction in infected-cured fruit with respect to control non-treated fruit. Moreover,

22 this result suggests that induction of PAL might be partially responsible for the

23 highest scoparone levels found in the flavedo and albedo of infected-cured fruit

24 (Table 2). Interestingly, wounding followed by the curing treatment led to a $13 \%$ and

$2533 \%$ reduction in disease incidence with respect to control and cured fruits, 
1 respectively (Table 1). Although scoparone levels in the flavedo and albedo of

2 wounded-cured fruit were 10 and 40 fold lower, respectively, than in the same tissues

3 of infected-cured fruit (Table 2), disease incidence was only $10 \%$ higher than in

4 infected-cured fruit and no significant differences in disease severity were observed

5 (Table 1). This lack of correlation between disease resistance and scoparone levels,

6 which has been classically considered a marker induced resistance in citrus fruit (Kim

7 et al., 1991; Ben Yehoshua et al., 1992; Droby et al., 2002; Venditti et al., 2005),

8 suggests that induced resistance must also rely on other factors.

9 Our results suggest that, besides PAL, soluble peroxidase might contribute to the 10 beneficial effect of the infection-curing treatment reducing disease incidence of a 11 subsequent infection as the highest activity was found in the flavedo and the albedo of 12 infected-cured fruit. In concordance with this idea, soluble peroxidase activity also increased, but to a lower level, in response to wounding-curing, a treatment that also increased fruit's resistance. In this regard, it is noteworthy that peroxidase activity increases in citrus fruit elicited by UV irradiation (Droby et al., 1993) and in response 16 to P. digitatum infection (Ballester et al., 2006). We cannot rule out the participation 17 of insoluble peroxidase, which has been related to cell wall lignification, in the induced resistance, but this enzyme appears not to be as relevant as soluble peroxidase 19 since no significant difference in this activity was found between wounded-cured fruit 20 and the infected-cured ones in spite of the higher efficacy of the latter treatment.

21 Overall changes in peroxidase activity seem to be more related to induction of pox1 22 gene expression than to pox2, as the former gene, which codes for a basic isoform, 23 parallels peroxidase activity.

$24 \quad \beta-1,3$-glucanases and chitinases can potentially degrade the fungal cell wall, mainly 25 composed by $\beta$-1,3-glucan and chitin (van Loon et al., 2006). PR proteins have a dual 
1 cellular localization: acidic proteins are extracellular, whereas basic proteins are

2 located into vacuoles. Generally, $\beta$-1,3-glucanase and chitinase basic isoforms have

3 more inhibitory effect on pathogens than acidic isoforms (Joosten et al., 1995).

4 Interestingly, we have found that the expression of gns1, chi1 and pox1, all coding for

5 basic isoforms, increased in response to the infection-curing treatment, whereas the

6 acidic enzyme-encoding genes chi2 and pox2 were not induced. CrglcQ, coding for an

7 acidic $\beta$-1,3-glucanase, showed a particular behavior, as treatments that led to an

8 increase in disease resistance induced the accumulation of the larger transcript but had

9 no effect on the smaller one. It is important to note that all the genes coding for basic

10 isoforms were isolated from a cDNA library derived from mandarin fruits infected

11 with $P$. digitatum and that their pattern of expression in response to the treatment that

12 elicited fruit resistance was similar to that of changes in the activity of their respective

13 enzymes. Therefore, they might play a role delaying fungal growth and decreasing the

14 incidence of the infection caused by P. digitatum in citrus fruit. Chitinase and $\beta-1,3-$

15 glucanase proteins were also induced in the flavedo of citrus fruit treated with a

16 biocontrol yeast (Droby et al., 2002). It is also noteworthy that the expression of gns1

17 increased in response $P$. digitatum infection, wounding, ethylene or to treatments that

18 increase the resistance to $P$. digitatum, such as UV-irradiation, biocontrol agents,

19 jasmonic acid or $\beta$-amino butyric acid (Porat et al., 2002).

20 In summary, this work presents a comprehensive approach to analyze simultaneously

21 the biochemical and molecular mechanisms underlying induced resistance in citrus

22 fruit against $P$. digitatum. Our data on gene expression and enzymatic activities in the

23 two tissues that compose the citrus rind suggest that PAL and soluble peroxidase are

24 involved in the induction of resistance of citrus fruit against P. digitatum infection.

25 Moreover, basic $\beta$-1,3-glucanase and chitinase isoforms, but not their acidic 
1 counterparts, may play a role increasing the fruit's defense capabilities. Finally, the

2 response deployed by the albedo correlates better than that of the flavedo with the

3 observed increase in disease resistance in citrus fruit, a fact that has been overlooked

4 in previous studies.

5

6 ACKNOWLEDGEMENTS

7 We thank Drs J. Sendra and E. Sentandreu for their help with HPLC analysis. This

8 work was supported by Research Grants AGL2000-1443 and AGL2002-1227 from

9 the Spanish Ministry of Science and Technology and GRUPOS03/-008 from the

10 Valencian Agency of Science and Technology.

11 


\section{REFERENCES}

Abeles, F.B. and Forrence, L.E., 1970. Temporal and hormonal control of beta-1,3glucanase in Phaseolus vulgaris L. Plant Physiol. 45, 395-400.

Afek, U., Orenstein, J., Carmeli, S., Rodov, V., Joseph, M.B., 1999. Umbelliferone, a phytoalexin associated with resistance of immature Marsh grapefruit to Penicillium digitatum. Phytochemistry 50, 1129-1132.

Angioni, A., Cabras, P., D'hallewin, G., Pirisi, F.M., Reniero, F., Schirra, M., 1998. Synthesis and inhibitory activity of 7-geranoxycoumarin against Penicillium species in Citrus fruit. Phytochemistry 47, 1521-1525.

Arcas, M.C., Botia, J.M., Ortuño, A.M., Del Río, J.A., 2000. UV irradiation alters the levels of flavonoids involved in the defence mechanism of Citrus aurantium fruits against Penicillium digitatum. Eur. J. Plant Pathol. 106, 617-622.

Arras, G., 1996. Mode of action of an isolate of Candida famata in biological control of Penicillium digitatum in orange fruits. Postharvest Biol. Technol. 8, 191-198.

Ballester, A.R., Lafuente, M.T., González-Candelas, L., 2006. Spatial study of antioxidant enzymes, peroxidase and phenylalanine ammonia-lyase in the citrus fruit-Penicillium digitatum interaction. Postharvest Biol. Technol. 39, 115-124.

Ben Yehoshua, S., Rodov, V., Kim, J.J., Carmeli, S., 1992. Preformed and induced antifungal materials of citrus fruit in relation to the enhancement of decay resistance by heat and ultraviolet treatment. J. Agric. Food Chem. 40, 12171221.

Brown, G.E., Ismail, M.A., Barmore, C.R., 1978. Lignification of injuries to citrus fruit and susceptibility to green mold. Proc. Fla. State Hort. Soc. 91, 124-126. 
1 Droby, S., Chalutz, E., Horev, B., Cohen, L., Gaba, V., Wilson, C.L., Wisniewski, M., 1993. Factors affecting UV-induced resistance in grapefruit against the green mold decay caused by Penicillium digitatum. Plant Pathol. 42, 418-424.

Droby, S., Vinokur, V., Weiss, B., Cohen, L., Daus, A., Goldschmidt, E.E., Porat, R., 2002. Induction of resistance to Penicillium digitatum in grapefruit by the yeast biocontrol agent Candida oleophila. Phytopathology 92, 393-399.

Fajardo, J.E., McCollum, T.G., McDonald, R.E., Mayer, R.T., 1998. Differential induction of proteins in orange flavedo by biologically based elicitors and challenged by Penicillium digitatum Sacc. Biol. Control 13, 143-151.

Forment, J., Gadea, J., Huerta, L., Abizanda, L., Agusti, J., Alamar, S., Alos, E., Andres, F., Arribas, R., Beltrán, J.P., Berbel, A., Blazquez, M.A., Brumos, J., Canas, L.A., Cercos, M., Colmenero-Flores, J.M., Conesa, A., Establés, B., Gandia, M., García-Martínez, J.L., Gimeno, J., Gisbert, A., Gomez, G., González-Candelas, L., Granell, A., Guerri, J., Lafuente, M.T., Madueno, F., Marcos, J.F., Marques, C., Martinez, F., Martínez-Godoy, M.A., Miralles, S., Moreno, P., Navarro, L., Pallás, V., Perez-Amador, M.A., Perez-Valle, J., Pons, C., Rodrigo, I., Rodriguez, P.L., Royo, C., Serrano, R., Soler, G., Tadeo, F., Talón, M., Terol, J., Trenor, M., Vaello, L., Vicente, O., Vidal, Ch., Zacarías, L., Conejero, V., 2005. Development of a citrus genome-wide EST collection and cDNA microarray as resources for genomic studies. Plant Mol. Biol. 57, $375-391$.

Joosten, M.H.A.J., Verbakel, H.M., Nettekoven, M.E., van Leeuwen, J., van der Vossen, R.T.M., de Wit, P.J.G.M., 1995. The phytopathogenic fungus Cladosporium fulvum is not sensitive to the chitinase and $\beta$-1,3-glucanase defence proteins of its host, tomato. Physiol. Mol. Plant Pathol. 46, 45-59. 
1 Kavanagh, J.A. and Wood, R.K.S., 1967. The role of wounds in the infection of oranges by Penicillium digitatum Sacc. Ann. Appl. Biol. 60, 375-383.

3 Kim, J.J., Ben Yehoshua, S., Shapiro, B., Henis, Y., Carmeli, S., 1991. Accumulation

López-García, B., González-Candelas, L., Pérez-Payá, E., Marcos, J.F., 2000. Identification and characterization of a hexapeptide with activity against of scoparone in heat-treated lemon fruit inoculated with Penicillium digitatum Sacc. Plant Physiol. 97, 880-885. phytopathogenic fungi that cause postharvest decay in fruits. Mol. PlantMicrobe Interact. 13, 837-846.

Lurie, S., Fallik, E., Handros, A., Shapira, R., 1997. The possible involvement of peroxidase in resistance to Botrytis cinerea in heat treated tomato fruit. Physiol. Mol. Plant Pathol. 50, 141-149.

Marcos, J.F., González-Candelas, L., Zacarías, L., 2005. Involvement of ethylene biosynthesis and perception in the susceptibility of citrus fruits to Penicillium digitatum infection and the accumulation of defense-related mRNAs. J. Exp. Bot. 56, 2183-2193.

McCollum, T.G., Doostdar, H., Niedz, R.P., Mayer, R.T., Burkhart, M., McDonald, R.E., 1999. Biochemical, molecular genetic, and immunological characterization of a $\beta-1,3$-endoglucanase from 'Valencia' orange callus. J. Plant. Physiol. 155, 16-23.

Nafussi, B., Ben Yehoshua, S., Rodov, V., Peretz, J., Ozer, B.K., D'hallewin, G., 2001. Mode of action of hot-water dip in reducing decay of lemon fruit. J. Agric. Food Chem. 49, 107-113. 
1 Ortuño, A., Baidez, A., Gomez, P., Arcas, M.C., Porras, I., Garcia-Lidon, A., Del Rio, J.A., 2006. Citrus paradisi and Citrus sinensis flavonoids: Their influence in the defence mechanism against Penicillium digitatum. Food Chem. 98, 351-358.

Osswald, W.F., Shapiro, J.P., Doostdar, H., McDonald, R.E., Niedz, R.P., Nairn, C.J., Hearn, C.J., Mayer, R.T., 1994. Identification and characterization of acidic hydrolases with chitinase and chitosanase activities from sweet orange callus tissue. Plant Cell Physiol. 35, 811-820.

Porat, R., Lers, A., Dori, S., Cohen, L., Weiss, B., Daus, A., Wilson, C.L., Droby, S., 1999. Induction of chitinase and beta-1,3-endoglucanase proteins by UV irradiation and wounding in grapefruit peel tissue. Phytoparasitica 27, 1-6.

Porat, R., McCollum, T.G., Vinokur, V., Droby, S., 2002. Effects of various elicitors on the transcription of a $\beta-1,3$-endoglucanase gene in citrus fruit. J. Phytopathol. $150,70-75$.

Porat, R., Vinokur, V., Holland, D., McCollum, T.G., Droby, S., 2001. Isolation of a citrus chitinase cDNA and characterization of its expression in response to elicitation of fruit pathogen resistance. J. Plant. Physiol. 158, 1585-1590.

Rodov, V., Ben Yehoshua, S., Kim, J.J., Shapiro, B., Ittah, Y., 1992. Ultraviolet illumination induces scoparone production in kumquat and orange fruit and improves decay resistance. J. Am. Soc. Hortic. Sci. 117, 788-792.

Sánchez-Ballesta, M.T., Gosalbes, M.J., Rodrigo, M.J., Granell, A., Zacarías, L., Lafuente, M.T., 2006. Characterization of a $\beta$-1,3-glucanase from citrus fruit as related to chilling-induced injury and ethylene production. Postharvest Biol. Technol. 40, 133-140. 
1 Sánchez-Ballesta, M.T., Lafuente, M.T., Zacarías, L., Granell, A., 2000. Involvement of phenylalanine ammonia-lyase in the response of Fortune mandarin fruits to cold temperature. Physiol. Plant. 108, 382-389.

4 van Loon, L.C., Rep, M., Pieterse, C.M.J., 2006. Significance of inducible defense5 related proteins in infected plants. Annu. Rev. Phytopathol. 44, 135-162.

6 Venditti, T., Molinu, M.G., Dore, A., Agabbio, M., D'hallewin, G., 2005. Sodium carbonate treatment induces scoparone accumulation, structural changes, and alkalinization in the albedo of wounded Citrus fruits. J. Agric. Food Chem. 53, $3510-3518$.

World Trade Organization. 2009. Effects of SPS-related private standards -

report

Note

by

the

Secretariat. http://ec.europa.eu/food/international/organisations/sps/otherissues en.print.htm Document G/SPS/GEN/932. 


\section{FIGURE LEGENDS}

Fig. 1. Flow chart of the experimental design. Solid arrows indicate the temperature and duration of the incubation period. The induction of resistance treatment (panel A) consisted of fruit inoculated with $P$. digitatum and then incubated for 1 day at $20^{\circ} \mathrm{C}$ before being transferred at $37^{\circ} \mathrm{C}$ for 3 days to stop pathogen progress. At the end of this heat treatment, fruit were maintained at $20^{\circ} \mathrm{C}$. After 3 days of incubation at $20^{\circ} \mathrm{C}$ ( $3 \mathrm{dpt})$, tissue samples were taken from 15 fruits and other 15 oranges were inoculated with $P$. digitatum to asses the effectiveness of the treatment. Infection was allowed to progress for 6 days, when disease incidence and severity were determined. Mock control fruit were wounded and inoculated with sterile water (panel B). Additional control non-wounded and heated fruit were also included (panel C). Control non-treated fruit (NT) were sampled at the beginning of the experiment (panel D). Letters in panels indicate when samples were taken for analysis. Inoculation with P. digitatum is indicated as Pdig.

Fig.. 2. Accumulation of FPal1 mRNA (A) and PAL activity (B) in the flavedo and albedo of elicited 'Navelate' oranges. Intact oranges were incubated 1 day at $20^{\circ} \mathrm{C}$ followed by 3 days at $37^{\circ} \mathrm{C}$ (C). Wounded fruit were inoculated with either water (W) or a $P$. digitatum spore suspension (I) and incubated for $24 \mathrm{~h}$ at $20^{\circ} \mathrm{C}$ and 3 days at $37^{\circ} \mathrm{C}$. At 3 days post-treatment peel tissue discs of $13 \mathrm{~mm}$ in diameter around the inoculation site were sampled by using a cork borer. Tissue from non-treated fruit (NT) was obtained the first day of the experiment. (A) Relative accumulation (R. A.) of FPal1 mRNA in arbitrary units, using the non-treated flavedo tissue as a reference. Normalization was carried out with respect to the hybridization signal of the C. sinensis $26 \mathrm{~S}$ rDNA probe. (B) Enzyme activity data represent the average of 3 
1 replicates samples \pm SD. Different letters in the same tissue indicate significant differences among treatments according to Tukey's test with a $p$-value of 0.05 .

Fig. 3. Effect of the induction of resistance treatment on the accumulation of pox 1 and pox2 mRNAs (A) and soluble and insoluble peroxidase activities (B) in flavedo and albedo of elicited 'Navelate' oranges. Intact oranges were incubated for 1 day at $20^{\circ} \mathrm{C}$ and 3 days at $37^{\circ} \mathrm{C}(\mathrm{C})$. Wounded fruit were inoculated with either water (W) or a P. digitatum spore suspension (I) and incubated for $24 \mathrm{~h}$ at $20^{\circ} \mathrm{C}$ and $3 \mathrm{~d}$ at $37^{\circ} \mathrm{C}$. At 3 days post-treatment peel tissue discs of $13 \mathrm{~mm}$ in diameter around the inoculation site were sampled by using a cork borer. Tissue from non-treated (NT) fruit was obtained the first day of the experiment. (A) Relative accumulation (R. A.) of pox1 and pox2 mRNAs in arbitrary units, using the non-treated flavedo tissue as a reference. Normalization was carried out with respect to the hybridization signal of the $C$. sinensis $26 \mathrm{~S}$ rDNA probe. (B) Enzyme activity data represent the average of 3 replicates samples $\pm \mathrm{SD}$. Different letters in the same tissue indicate significant differences among treatments according to Tukey's test with a $p$-value of 0.05 .

Fig. 4. Accumulation of gns1 and CrglucQ mRNAs (A) and $\beta$-1,3-glucanase activity (B) in flavedo and albedo of elicited 'Navelate' oranges. Wounded fruit were inoculated with either water (W) or a $P$. digitatum spore suspension (I) and incubated for 1 day at $20^{\circ} \mathrm{C}$ and 3 days at $37^{\circ} \mathrm{C}$. Intact oranges were maintained 1 day at $20^{\circ} \mathrm{C}$ and 3 days at $37^{\circ} \mathrm{C}(\mathrm{C})$. At 3 days post-treatment peel tissue discs of $13 \mathrm{~mm}$ in diameter around the inoculation site were sampled by using a cork borer. Tissue from non-treated fruit (NT) was obtained the first day of the experiment. (A) Relative accumulation (R. A.) of gns1 and CrglcQ mRNAs in arbitrary units, using the non- 
1 treated flavedo tissue as a reference. Normalization was carried out with respect to the

2 hybridization signal of the C. sinensis 26S rDNA probe. (B) Enzyme activity data

3 represent the average of 3 replicates samples \pm SD. Different letters in the same tissue

4 indicate significant differences among treatments according to Tukey's test with a $p$ -

5 value of 0.05

6

7 Fig. 5. Effect of the induction of resistance treatment on the accumulation of chi1 and 8 chi2 mRNAs (A) and chitinase activity (B) in flavedo and albedo of elicited 9 'Navelate' oranges. Intact fruit were maintained 1 day at $20^{\circ} \mathrm{C}$ and 3 days at $37^{\circ} \mathrm{C}(\mathrm{C})$.

10 Wounded fruit were inoculated with either water (W) or a P.digitatum spore 11 suspension (I) and incubated for $24 \mathrm{~h}$ at $20^{\circ} \mathrm{C}$ and $3 \mathrm{~d}$ at $37^{\circ} \mathrm{C}$. At 3 days post12 treatment peel tissue discs of $13 \mathrm{~mm}$ in diameter around the inoculation site were 13 sampled by using a cork borer. Tissue from non-treated fruit (NT) was obtained the 14 first day of the experiment. (A) Relative accumulation (R. A.) of chi1 and chi2 15 mRNAs in arbitrary units, using the non-treated flavedo tissue as a reference. 16 Normalization was carried out with respect to the hybridization signal of the 17 C. sinensis 26S rDNA probe. (B) Enzyme activity data represent the average of 3 18 replicates samples \pm SD. Different letters in the same tissue indicate significant 19 differences among treatments according to Tukey's test with a p-value of 0.05 . 